\title{
Implementation of Palu City Local Policy on Guidance and Control of Creative Field Traders
}

\author{
Selamet Riadi \\ Faculty of Social and Political Science, Tadulako University, Central Sulawesi, Indonesia \\ selamatriadi990@gmail.com
}

\begin{abstract}
The formulation of the problem in this research is how the implementation of policy of Guidance and Control of Field Creative Commerce in Palu City, while the purpose of this research is to know How to implement policy of Guidance and Control of Field Creative Trade in Palu City. The research method used is descriptive qualitative. The result of the research shows that the implementation of policy of Guidance and Control of Field Creative Commerce in Palu City has not been implemented well. It can be seen from communication indicator, resources, disposition and bureaucracy structure. Some aspects that still need to be improved as in the case of coordination among authorized agencies within the framework of arranging, fostering and controlling the Field Creative Traders are not mutually throwing responsibility in terms of their implementation. The approach undertaken to discipline the Field Creative Traders is still limited to persuasive approach and still only directed by the Official and Palu City of Palu. In addition, the provision of facilities and infrastructure such as places of sale must be provided in accordance with the wishes of the merchant that is to find a strategic place to sell.
\end{abstract}

Keywords: implementation; communication; resources; disposition and bureaucratic structure.

\section{Introduction}

The increasing number of unbalanced workforce with the narrowness of formal employment resulted in an increase in unemployment. This causes many people who then work or try in the informal sector such as Field Creative Traders in major cities in Indonesia. Field Creative Merchants arise as a result of the unavailability of jobs for the small people who lack the ability to produce. In addition, the consequences of liberal economic policies tend to favor macroeconomic growth and ignore microeconomics. The Indonesian Field Creative Merchants Association (APKLI) notes that until 2012 there were 23.4 million Field Creative Merchants throughout Indonesia (Tempo.co, 5/9/2012). Street vendors are seen as illegal activities and sometimes treated like criminals.

Studies show that almost in all Asian countries, street vendors do not have legal status in running their business and they continue to get violent acts by the city government with a program in the name of ordering or structuring. On the other hand, the role of the informal sector including PKL has not been fully accepted by the city government.

Street vendors are viewed more as non-profit activities, because they do not contribute to the local or national economy through taxes. They are marginalized on the development agenda, thereby adversely affected by socio-economic macro policies. Limited policy support, making the sector unsafe and adversely affecting the livelihoods of the urban poor. They are notorious for giving some urban residents the need for goods or services that cannot be provided by large retail outlets. The facts show that street vendors are an important source of livelihood for the urban poor. PKL activities generally occupy road bodies and sidewalks, leaving no room for pedestrians. This condition is a public concern because it 
creates congestion problems and movement of people in the pedestrian, and creates a dirty and unhealthy environment. Street vendors who occupy space and public roads can also create social problems such as the presence of pickpockets, thieves, and so forth. This situation creates problems in the management of development and destroys the morphology and aesthetics of the city.

However, for some community groups, street vendors actually become a solution, because it provides cheaper price. For low income people, street vendors are an option. This makes the curbing of street vendors in strategic locations to be controversial viewed from the social glass. Yet every day, they are tenacious workers, struggling to support the family. With the Presidential Regulation number 125 of 2012 and the Regulation of the Minister of Home Affairs number 41 of 2012, the Provincial Government and the Municipal / District Government shall conduct structuring and fostering street vendors in their respective areas. One of the mandates contained in Permendagri number 41 of 2012 is the Regent / Mayor specify the location or area according to its designation as the location where the business activities of street vendors.

Determination of location or area where PKL business activity is taking into account public interest, social, culture, aesthetics, economy, security, orderliness, health, environmental hygiene and in accordance with the Regional Regulation on Spatial Planning of Province and Regency / Municipality. The location where the business activities of the street vendors is a permanent or temporary location of the Regent / Mayor and has been equipped with signage of the location and signs or signs explaining the limits of the number of street vendors in accordance with the laws and regulations. In addition, the Regent / Mayor is also required to empower street vendors through enhancement of business capability; facilitation of access to capital; facilitation of trade facilities assistance; institutional strengthening; facilitation of increased production; processing, network development and promotion; and coaching and technical guidance.

While the empowerment of street vendors that require cooperation between regencies / cities is done by the government .In carrying out the empowerment and arrangement of street vendors, Palu Mayor can conduct cooperation or partnership with business world through Corporate Social Responsibility (CSR) program in the form of rejuvenation of business place of street vendors; improvement of entrepreneurship capability through guidance, training and capital assistance; business promotion and event at the target location; and play an active role in the arrangement of street vendors in urban areas to become more orderly, clean, beautiful and comfortable.

Palu City Government has issued Palu City Local Regulation No. 3 of 2011 on Guidance and Control of the Field Creative Commerce, if you see the regulation issued more than ten years about the Guidance and Law Enforcement of the Field Creative Commerce in the hammer set, however, the arrangement of the Field Creative Merchants in Palu City still impressed chaotic is not inscribed with so, giving a portrait of Palu City is still impressed slum and chaotic With that reality then, Implementation Rules Palu City No. 3 of 2011 on Guidance and Control of Field Creative Merchants tend not maximal. 


\section{Review of Literature}

Public policy implementation model proposed by Edward III pointed four variables that play an important role in achieving successful implementation. The four variables are communication, resources, disposition, and biosystem structure.

a) Communication, ie the success of policy implementation requires that the implementation know what to do. What turns them on and policy goals should be transmitted to the target group so that it will reduce the implementation distortion. If the goals and objectives of a policy are unclear or even unknown to the target group, then there is a possibility of resistance from the target group.

b) Source, that is, each policy must be supported by adequate resources both human resources and financial resources. Human resources is the adequacy of both the quality and quantity of implementation that can cover all target groups. Financial resources is the capital adequacy of investment on a program / policy. Both must be considered In the implementation of the program / policy of the government. Because without the reliability of the implementation of the policy becomes less energetic and run slowly and sober. While the financial resources ensure sustainability program / policy. Without adequate financial support the program cannot run effectively and quickly in achieving goals and objectives.

c) Disposition, ie character and characteristics possessed by the implementation, such as commitment, honesty, democratic nature. If the idealist has a good position, then he or she will be able to run the policy as well as what the policy maker wants. When the implementation has different attitudes or perspectives with the policy maker, the policy implementation process also becomes ineffective.

d) Bureaucratic structure, the organizational structure in charge of implementing the policy has a significant influence on the implementation of the policy. One of the most important structural aspects of any organization is the existence of standard operating procedures (SOPs). SOPs serve as guidelines for every implementation in action. An overly long organizational structure will tend to undermine surveillance and lead to red-tape, complicated and complex bureaucratic procedures, ultimately inflexible organizational activity.

\section{Methodology}

The approach used in analyzing the implementation of policy on Guidance and Control of Field Creative Traders is the theory proposed by George C. Edwards III. Where implementation can start from abstract conditions and a question about whether the requirements for policy implementation can work, according to George C. Edwards III there are four variables in public policy that are Communications, Resources, attitudes or attitudes bureaucratic structure (bureucratic structure). 


\subsection{Communication}

\section{Discussion}

In the context of policy implementation, communication is needed because the success of policy implementation depends on how the implementor communicates the policy to be implemented.

Most policies fail because of lack of communication between the policy implementer in this case the government and the community as objects of the policy itself. The rise of Creative Field Merchants in Palu City gives an opaque portrait of chaotic city arrangement. The merchants just open the stalls without paying attention to the regulations that have been set by the local government, whereas the rules on the Field Creative Traders have been issued by the local government in the form of Local Regulation (Perda) No. 3 of 2011 on Guidance and Control of Field Creative Traders in Palu CityThe lack of communication made by crosssectoral or in related offices make the arrangement of the city of hammer still impressed slum,In the Field Creative Merchant arrangement required a good communication of the process undertaken, not necessarily do the action by the officers to create a friendly atmosphere and a sense of kinship between the officers either Satpol PP or related offices. With the creation of good communication by Satpol PP unit can provide settlement arrangement and does not cause conflict between officers and the Field Creative Merchants in Palu City.In the case of communications, the Civil Service Police or POL PP performs several stages in completing and enforcing the local regulation on the Field Creative Merchant which gives warning to the merchant up to 3 (three) times later if the Field Crater Traders do not heed the Civil Service Police Unit (POL-PP) has just taken action, so that no Field Creative Merchant is not aware of the Guidance and Control of the Field Creative Merchants.

\subsection{Resource}

Resources are important in implementing the policy, because without adequate support of resources it is very influential on the success of policy implementation. The resources in question can be Human Resources (SDM) or Natural Resources (SDA). Both of these resources must support each other in order that the implemented policy can achieve the target.

Understanding of Field Creative Merchants on the place of selling on the roadside is still minimal, this is due to the lack of socialization that is done by the Office of Action and SMEs City hammer. Merchants Creative Field only trade in crowded places in the pass by the community to easily market their sales to buyers. Even the city government has provided and built a place to sell but ignored by the Field Creative Traders because the provided by the government is inadequate in terms of facilities and infrastructure and transportation access to places that have been provided is very limited. Provision of suggestions and infrastructure by the city government of Palu is not maximally utilized by street vendors because they are only looking for a place that is easy to pass by buyers and many consumers. In terms of provision of proper place the government provides a more strategic place to be able to sell so that the Field Creative Merchants can get a lot of visitors. Understanding of pedestals for street vendors or sidewalks is partly understood, but relatively small places and incomes sometimes make Field Creative Brokers often violate the municipal government's hammer rules, it can be seen that there are still many Field Creative Merchants selling on the sidewalks and on the 
sidewalk. By it it takes the commitment and efforts of the city government to be able to continue to provide guidance and understanding of the problems related to the arrangement of the Field Creative Traders, especially in the city of Palu.

\subsection{Disposition}

Disposition is the attitude or behavior of apparatus in implementing the policy, the extent to which the implementer implements the policy whether it can be accepted by the policy object. In the context of policy approaches that are used are needed in order to achieve the policy objectives. The policy implementer has a responsibility in guarding the success of a policy, by which it must be full of trust and responsibility so that the implemented policy can solve the problem rather than just the opposite to increase the problem.

Controlling and fostering of Field Creative Merchants needs to be done humanist approaches to traders, because the issue of regulation is a matter of searching one's life, by it it is necessary that there are efforts made in the process of Guidance and Control does not cause conflict between the Field Creative Merchants with government apparatus city in the context of enforcement of local regulations.

So far, the Office of Perindakop and UKM of Palu City invites the street vendors to sit together as to how they sell well and occupy the space provided and they should clean up the garbage and bring home their merchandise so as not to scatter where they sell, such as existing traders in Vatulemo Square they are after selling to be encouraged to bring and clean their goods. So far, the Office of Perindakop and UKM of Palu City invites the street vendors to sit together as to how they sell well and occupy the space provided and they should clean up the garbage and bring home their merchandise so as not to scatter where they sell, such as existing traders in Vatulemo Square they are after selling to be encouraged to bring and clean their goods.

\subsection{Bureaucratic Structure}

The fourth indicator is the Bureaucratic Structure. Bureaucratic Structure is an important element in policy implementation, because the more complex problem faced by city government in organizing and fostering Field Creative Traders in need of effective and efficient bureaucracy structures besides that there need to be coordination cross sector in settlement clutter arrangement of Field Creative Traders in Palu City.

To organize and discipline the Field Creative Merchants is required cross-agency cooperation or agency because they have interrelated duties and functions. For example, in relation to the road problem, the transportation authority has the right to discipline and when leaving the garbage strewn, the duty office is obliged to affirm it and for the development and progress of the business will be built by the Office of the Puskesmas and SMEs so that each other is related to the Guidance and Control of the Field Creative Commerce in City of Palu.

In organizing and fostering the Field Creative Merchants there is no need for a large amount of bureaucracy, if it can be done with a persuasive and humanist approach to the Field Creative Merchants, because they are also knowledgeable people if they are provided with good socialization and understanding hence conflicting tendency between officers and Field Creative Merchants, can be minimized. 


\section{Conclusion}

a. The government needs to provide a place to sell in places where the Creative Field strategy does not roam the sidewalks.

b. Enforcement of stricter local regulations is needed

c. We recommend in the arrangement of the Field Creative Merchants in Palu City to adjust the master plan of city hammer arrangement so as not to impress slums and chaotic.

d. It is preferable that a partner's authority establish a communication system for good coordination.

\section{A. Books}

\section{References}

Anderson, James E, 2006, Publik Policy Making: An Introduction, Boston: Hounghton Mifflin Company.

Agustino, Leo. 2006. Politik dan Kebijakan Publik. Bandung : Penerbit AIPI Bandung dan Puslit KP2W Lemlit Unpad.

Anderson, J. E. 1979. Public Policy Making: An Introduction,. Boston: Houghton Mifflin Company.

Blower JH, Jan Wind, Harry Amir, 1977, Proposed Lore Kalamanta National Park, Management Plan 1978-1980, fAO/UNDP, Bogor.

Danin, Sudarwan., 1997. Pengantar Studi Penelitian Kebijakan, Bumi Aksara, Jakarta

Dunn N William, 2003. Pengantar Analisis Kebijakan Publik (Edisi kedua), Gadjah Mada University Press, Yogyakarta.

Edwards III, George C. 1980. Implementing Public Policy. Washington: Congressional Quarterly Inc.

Grindle, Merile S. (ed). 1980. Politics and Apolicy Implementation in Third World, New Jersey : Princetown University Press.

Islamy, M.irfan, Prinsip-prinsip Perumusan Kebijaksanaan Negara, Bumi Aksara, Jakarta, 2000.

Jones, Charles O. 1984. Pengantar Kebijakan Publik (terjemahan). Jakarta: PT. Raja Grafindo Persada.

--- An Introduction to the study of Public Policy. Wads Worth, Inch.

Islamy, Irfan M. 1984. Prinsip-Prinsip Perumusan Kebijaksanaan Negara. Jakarta: Bina Aksara.

Keban, Y.T., 2004. Enam Dimensi Strategis Administrasi Publik: Konsep, Teori, dan Isu. Yogyakarta Gramedia.

Nawawi, Hadari., 1982.Metode Penelitian Bidang Sosial, Gadjah Mada University Press, Yogyakarta.

Moleong, Lexi J., 2005, Metode Penelitian Kualitatif, Remaja Rosdakarya, Bandung.

McGee, TG and YM Yeung, 1977. Hawkers in Southeast Asian Cities: Planning for the Bazaar Economy. IDRC Ottawa, Canada.

Osbome, David \& Ted Gaebler. 1993. Reinventing Government: How the Entrepreneurial Spirit is transforming The Public Sector. Massachusetts, USA: Addison-Wesley Publishing Company Inc. 
Osborne, David \& Peter Plastrik, 2000. Memangkas Birokrasi: Lima Strategi Menuju Pemerintahan Wirausaha. Penerbit: PPM.

Ripley, R.B. \& Franklin G. Congress. 1986. The Bureaucracy and Public Policy. Illionis: Dorsey Homewood.

Rusli, Budiman 2013. Kebijakan Publik, Membangun Pelayanan Publik yang Responsif, Bandung : Hakim Publishing.

Sanapiah Faisal, 1989. Format-format Penelitian Sosial, Jakarta : Rajawali Press.

Saifuddin Anwar, 2001. Metode Penelitian, Pusaka Pelajar, Yogyakarta.

Sugiyono, 2005. MetodePenelitianAdministrasi, Alfabeta Bandung.

Singarimbun, Masri (ed)., 1989. Metode Penelitian Survey, LP3ES, Jakarta

Tamba, Halomoan dan Saudin Sijabat, 2006. Pedagang Kratif Lapangan: Entrepreneur yang Terabaikan. Infokop Nomor 29 Tahun XXII.

Wahab, Solichin Abdul. 2004. Analisis Kebijaksanaan dan Formulasi, ke Implementasi Kebijaksanaan Negara, Bumi Aksara, Jakarta.

Widodo, 2001. Good Governance, Telaah dari Dimensi dan Kontrol Birokrasi pada Era Desentralisasi dan Otonomi Daerah, Insan Cendikia, Bandung.

Winarno, 2004. Teori dan Proses Kebijakan Publik, Media Pressindo, Yogyakarta.

Widodo, Joko., Membangun Birokrasi Berbasis Kinerja, Bayumedia Publishing, Malang, 2008

Winarti, 2012. Analisa Kebijakan Penataan Pedagang Kratif Lapangan dari Perspektif Kebijakan Deliberatif. E-Journal UNISRI Volume XXIV No.1.

\section{B. Documents}

Regulation of the President of the Republic of Indonesia Number 125 Year 2012 Concerning Coordination of Structuring and Empowerment of Kratif Traders Field.

Regulation of the Minister of Home Affairs of the Republic of Indonesia No. 41 of 2012 on Guidelines for Structuring and Empowerment of Kratif Traders Field. 